Filling the gap in the European administrative space the role of administrative networks in EU implementation and enforcement Mastenbroek, Ellen; Martinsen, Dorte Sindbjerg

Published in:

Journal of European Public Policy

DOI:

10.1080/13501763.2017.1298147

Publication date:

2018

Document version

Publisher's PDF, also known as Version of record

Citation for published version (APA):

Mastenbroek, E., \& Martinsen, D. S. (2018). Filling the gap in the European administrative space: the role of administrative networks in EU implementation and enforcement. Journal of European Public Policy, 25(3), 422435. https://doi.org/10.1080/13501763.2017.1298147 


\section{Journal of European Public Policy}

\section{Filling the gap in the European administrative space: the role of administrative networks in EU implementation and enforcement}

\section{Ellen Mastenbroek \& Dorte Sindbjerg Martinsen}

To cite this article: Ellen Mastenbroek \& Dorte Sindbjerg Martinsen (2017): Filling the gap in the European administrative space: the role of administrative networks in EU implementation and enforcement, Journal of European Public Policy, DOI: 10.1080/13501763.2017.1298147

To link to this article: http://dx.doi.org/10.1080/13501763.2017.1298147
(c) 2017 The Author(s). Published by Informa UK Limited, trading as Taylor \& Francis Group
曲 Published online: 27 Mar 2017.

Submit your article to this journal $\sqrt{6}$

山 Article views: 89

Q View related articles 5

View Crossmark data $₫$ 


\title{
Filling the gap in the European administrative space: the role of administrative networks in EU implementation and enforcement
}

\author{
Ellen Mastenbroek ${ }^{a}$ and Dorte Sindbjerg Martinsen ${ }^{b}$ \\ anstitute for Management Research, Radboud University, Nijmegen, The Netherlands; \\ ${ }^{b}$ Department of Political science, University of Copenhagen, Copenhagen, Denmark
}

\begin{abstract}
European administrative networks (EANs) are a key building block of the European Administrative Space (EAS). Crucially, they are to fill the gap between the EU's policy ambitions and its limited administrative capacities. Whereas ample research has been done on policy preparation networks, the role of implementing EANs has received less attention in the EAS literature. This article fills this gap by providing a systematic review of relevant insights in four adjacent literatures: EU governance; international relations; public administration; and EU compliance. Employing a systematic literature review, it reports divergent findings on EAN establishment, functioning and impact, as well as variant normative evaluations. These variant findings partly relate to a lack of comparative research, selective policy coverage and predominant focus on North-western states. We conclude by suggesting a number of lines for future research on these four important themes, arguing that the crucial question will be which impact these EANs have on the national implementation and enforcement of EU law.
\end{abstract}

KEYWORDS European administrative networks; European administrative space; European Commission; enforcement; implementation; regulatory governance.

\section{Introduction}

The European Commission is the core executive of the European Union (EU). However, its resources pale into insignificance compared to those of national administrations (Metcalfe 2000; Trondal 2010) and compared to its tasks (Olsen 2003: 514). Its lack of financial and personnel capacities complicates important administrative functions (Majone 2000). In addition, it has limited formal powers, especially in the realm of implementation and enforcement. Accordingly, the Commission depends on the loyal co-operation of national 
authorities to achieve policy outcomes (Majone 2000; Trondal and Peters 2013: 295).

To compensate for these deficiencies, the EU has developed a 'European Administrative Space (EAS)'1 ${ }^{1}$ or 'European Executive Order' (Trondal 2010): 'an area in which increasingly integrated administrations jointly exercise powers delegated to the EU in a system of shared sovereignty' (Hofmann 2008: 671). The existing EAS literature has mainly mapped the administrative space around the Commission's policy development and decision-making tasks, i.e., seconded national experts, European agencies and EU committees (Trondal 2010; Trondal and Peters 2013). A fourth type of EAS 'filling' are networks of national administrative entities with a task in implementation (Hofmann 2008). Recent years have seen an increase in work on these 'implementing EANs' in four literatures: EU governance (Börzel and Heard-Lauréote 2009); international relations theory (Raustiala 2002; Slaughter 2004); public administration (Danielsen and Yesilkagit 2014; Yesilkagit 2011); and EU compliance (Versluis and Tarr 2013). This article takes stock of these literatures ${ }^{2}$ with an aim of developing a research agenda to facilitate more systematic and comparative work on the role of EANs in EU implementation and enforcement. It does so along four main themes: conceptualization; establishment; functioning and impact of EANs (cf. Bach et al. 2016; Thatcher 2011). Consecutively, we reflect on the normative aspects of EANs. We conclude with an agenda for research, arguing that the crucial question for further research will be which impact these EANs have on the national implementation and enforcement of EU law.

\section{Conceptualizing European administrative networks}

The EAS refers to the institutionalization of common administrative capacity (Trondal and Peters 2013: 295). The literature has emphasized networks of national regulatory agencies - often dubbed European regulatory networks/ ERNs (Blauberger and Rittberger 2015; Coen and Thatcher 2005, 2008; Danielsen and Yesilkagit 2014; Maggetti 2014a, 2014b; Maggetti and Gilardi 2011, 2014; Newman 2008; Van Boetzelaer and Princen 2012; Yesilkagit 2011). Yet, several other terms have been used: networks (Versluis and Tarr 2013); transnational regulatory networks (Eberlein and Grande 2005); transnational administrative networks (Bach et al. 2016); transnational networks (Wilks 2005); administrative networks (Martens 2008a); and transgovernmental networks (Bignami 2005; Eberlein and Newman 2008; Hobolth and Martinsen 2013; Hollis 2010; Martens 2008b; Raustiala 2002; Slaughter 2004).

Arguably, all these labels refer to a particular type of EANs: networks that consist of institutional representatives of national executives - primarily departments and/or agencies - with tasks in the realm of national implementation or enforcement of EU policies. These 'implementing EANs' may also 
include European actors (Coen and Thatcher 2008; Eberlein and Newman 2008; Martens 2008b; Slaughter 2004; Thurner and Binder 2009). Whereas the literature has primarily focused on regulatory networks (Levi-Faur 2011), they can also be executive in nature ${ }^{3}$ (e.g., Hobolth and Martinsen 2013; Hollis 2010).

Whereas implementing EANs share overall membership features (representatives from national executives) and tasks (implementation or enforcement), they may differ considerably in structure and functions. The American literature on transgovernmental networks (TGNs) has come closest to a typology. While generally horizontal in structure, (Slaughter and Hale 2010: 358), TGNs vary according to their functions: information enforcement or harmonization networks (Slaughter 2004: 51-61). However, EANs may be more vertical or sectoral in structure, with considerable involvement of the Commission or a European agency (Bach and Ruffing 2013). They may span a wider range of functions than the TGN typology suggests. These unknowns call for further mapping of EAN functions, both in their own right and in comparison with their international counterparts.

\section{EAN establishment}

The original argument on EAN establishment is functionalist in nature. Networks close the gap between the supranational making and national implementation of common rules (Blauberger and Rittberger 2015: 369; Coen and Thatcher 2008; Dehousse 1997; Eberlein and Grande 2005: 99; Groenleer et al. 2010; Hofmann 2008: 666). By pooling resources (Börzel and HeardLauréote 2009), specifically expertise (Kelemen and Tarrant 2011: 924), EANs may foster problem-solving (Börzel and Heard-Lauréote 2009), enhance Community regulatory credibility and efficiency, and insulate independent regulatory agencies (IRAs) from political pressures (Coen and Thatcher 2005; Majone 2000). EANs thus form a logical response to the interdependencies of modern times (Busuioc 2016), combined with the reluctance to establish all too powerful EU-regulators (Blauberger and Rittberger 2015; Coen and Thatcher 2008: 60-61; Dehousse 1997; Eberlein and Newman 2008; Kelemen and Tarrant 2011; Thatcher and Coen 2008). Employing principal-agent (PA) theory, Coen and Thatcher $(2005,2008)$ consider the establishment of ERNs a form of 'double delegation' by the European Commission and national regulatory agencies - occurring after earlier delegation to those actors.

These functionalist theories have received extensive criticism. First, they do not serve to theorize the choice between three different delegation pathways, i.e., the Commission, EU agencies and EANs, or variations in design choices across policy-making areas and over time (Kelemen and Tarrant 2011). Second, functionalism is largely devoid of politics. Given the fact that the EU does not have one clear principal, understanding the creation of EANs 
requires careful studying of the various principals and their preferences (Dehousse 2008). This insight paves the way for a more political-strategic view of EAN establishment.

So far, the literature has not produced theoretical nor empirical consensus on the types of strategic considerations that matter for EAN establishment. ${ }^{4}$ Suggested variables include the degree of distributional conflict in a policy area (Kelemen and Tarrant 2011), governments' agreement on underlying policy objectives (Bignami 2005), and possibilities to engage in bypassing of national governments (Maggetti 2014a), institutional rivalry (Thatcher 2011) and bureaucratic self-interest (Busuioc 2016). Surprisingly, substantive policy preferences of key players have hardly received attention (but see Bignami 2005), which is a remarkable departure from delegation theories more broadly. Furthermore, Kassim and Wright (2009) have challenged the political view of EAN establishment for its neglect of the complexity of negotiations, the importance of external circumstances and the restraint of the Commission in dominating EANs (Kassim and Wright 2009).

Furthermore, the verdict on the use of functionalist versus political accounts is still out. Blauberger and Rittberger (2015), have argued that functionalist explanations have the best cards to explain the particular form of a co-ordination structure, while political explanations can explain variations in the particular design of such a structure. This integrative approach must still be empirically validated.

Non-rationalist explanations to EAN establishment have in general been rare. Coen and Thatcher $(2005,2008)$ alluded to the importance of informal resources and copying for the establishment of EANs (Coen and Thatcher $2005,2008)$ A key insight flowing from their work is that an understanding of network creation must encompass more than only the formal principals (Coen and Thatcher 2008). Furthermore, Kassim and Wright's work (2009) explains the establishment of the European Competition Network as contingent on a rather consensual, expertise-driven process of debate and deliberation.

Employing historical institutionalism, thirdly, Thatcher and Coen (2008) developed a historical account of the development of structures for implementation in three network sectors. They identified a gradual strengthening of EANs, owing to processes of layering and conversion. Mathieu (2015) showed that processes of EAN establishment in the field of telecommunication flowed from previous steps to establish and strengthen national agencies (Mathieu 2015). Thatcher (2011), finally, argued that the construction of formalized EANs may hinder the creation of strong European agencies. LeviFaur (2011), however, found that agencies may also replace networks, while hybrid institutional forms may also result.

The empirical insights on EAN establishment mostly derive from qualitative (comparative) case studies. Most attention has gone to network sectors such 
as competition policy (Blauberger and Rittberger 2015; Kassim and Wright 2009; McGowan 2005; Thatcher 2011; Wilks 2005), telecommunications (Blauberger and Rittberger 2015; Coen and Thatcher 2005, 2008; Eberlein and Grande 2005; Kelemen and Tarrant 2011; Majone 2000; Mathieu 2015; Thatcher 2011; Thatcher and Coen 2008) and energy (Coen and Thatcher 2005, 2008; Eberlein and Grande 2005; Eberlein and Newman 2008; Thatcher 2011; Thatcher and Coen 2008), at the expense of sectors of 'positive integration' like environment, social policy and food safety. As shown by Table 1 in the Online Appendix, no attention has been paid to the following (sub) domains: international trade; taxation; education; agriculture and fishing; undertaking laws; state subsidies; foreign policy; foreign aid; migration; employment; and structural/regional funds. It is not clear whether these sectors do not have EANs, or whether they simply have not been studied. Furthermore, all research, with the exception of Levi-Faur (2011) has concerned 'positive' cases, tracing back reasons for establishment of EANs. We recommend also following the opposite strategy, and testing hypotheses on EAN establishment in likely cases based on the independent variables, which would allow for stronger theory-testing. The recent work of Levi-Faur (2011), which has regulatory regimes as its unit of analysis, constitutes a good first step in that direction.

\section{EAN functioning}

According to Hofmann (2008), administrative co-operation has led to 'intensive and often seamless co-operation between national and supranational administrative actors and activities.' Kelemen and Tarrant (2011: 925), however, criticize this 'overly sanguine view', arguing that EANs sometimes actually are designed to be ineffective (ibid., 923). These divergent positions characterize the literature on the actual functioning of EANs, which revolves around three key factors which condition such functioning: the co-operation between network members; the Commission's control of the network; and the autonomy of the network members vis-à-vis national governments.

Firstly, Cengiz (2010) and Vifell and Sjögren (2014) reported active and stable co-operation in the European Competition Network and SOLVIT - an important antecedent of network functionality (Cengiz 2010; Vifell and Sjögren 2014). Others established variant co-operation within EANs, linked to the reputational considerations of participating agencies (Busuioc 2016) and levels of interdependence (Van Boetzelaer and Princen 2012). Recently, Heidbreder pointed to horizontal co-operation between national bureaucracies without much vertical co-ordination as improving the enforcement of international trade agreements (Heidbreder 2015).

Regarding the matter of control, most research concerns the role of the Commission in EANs - which is disputed. Martens (2008b) and Hobolth and 
Martinsen (2013) found the Commission to play a proactive role, using networks strategically. Busuioc (2016) sketched a series of strategic moves by the Commission aimed at conditioning EAN development. Levi-Faur (2011: 823) reported that both EU agencies and the Commission make considerable investments in institutionalizing EANs as their agents. However, this analysis builds on a rather institutional and remote operationalization of EAN independence - agenda control and financial relations. The analysis leaves open the question of behavioural patterns. Here, we should stress the evidence against Commission dominance. Kassim and Wright (2009), firstly, reported striking restraint of the European Commission within the European Competition Network, which is seen by some as a clever move by the Commission to 'engineer ever greater centralization of competition decision-making' (McGowan 2005: 1001). Other scholars, however, address the issue of control beyond the Commission, discussing how national interests control and restrict the capacities of EANs to push through regulatory harmonization (Coen and Thatcher 2008; Kelemen and Tarrant 2011).

Thirdly, several researchers have analysed the effects of EAN membership on national agencies' formal and de-facto autonomy vis-à-vis national governments. The assumption is that 'ERNs enable the Commission to indirectly draw on national regulatory agencies and leverage their authority in order to ensure consistent and effective application of EU regulation' (Eberlein and Newman 2008: 26). A crucial question, therefore, is whether EANs alter relationships between national agencies and their ministries (Danielsen and Yesilkagit 2014). Indeed, various researchers observed that EAN membership may actually serve to enhance agency autonomy (Bach and Ruffing 2013; Danielsen and Yesilkagit 2014). As stressed by Yesilkagit (2011: 967), autonomy of national agencies may derive from institutional compliance with EU legislation, expertise and knowledge production by the EAN (Yesilkagit 2011).

According to Egeberg (2006), however, we should distinguish between the several stages of the policy cycle. During policy development and transposition, agencies are fairly attentive to their ministers (ibid., 10). These cannot be bypassed during transposition, given the need for binding national decisions (Bach et al. 2015). During implementation, however, the agencies' more often act on behalf the Commission and sister agencies in the network (Egeberg 2006: 10-11). Finally, as shown in Table 1 (Online Appendix), the above results are based on a small, non-representative sample of states: Germany; the Netherlands; Sweden; Finland; Denmark; and nonmember Norway.

\section{EAN impact}

The litmus test for EANs concerns their actual impact: can they really close the 'implementation gap' they are to solve? Thus impact concerns the ability of 
EANs to realize their policy objectives, such as improved national implementation or more harmonized enforcement of EU law. Several authors have documented EANs' role in adopting and promoting common standards at the national level (Maggetti 2014a: 493; Maggetti and Gilardi 2011; Maggetti and Gilardi 2014). Reportedly, this is especially the case for national agencies with network centrality (Maggetti and Gilardi 2011) and for EANs where supranational actors play a 'nodal role' (Versluis and Tarr 2013). EANs are found to be effective in 'closing the existing regulatory lacunae at the European level' (Eberlein and Grande 2005: 106), albeit to varying degrees across member states (Hobolth and Martinsen 2013). Crucial, again, seems to be national agencies' formal autonomy from the ministry (Yesilkagit 2011). However, other scholars remain sceptical about EANs capacity to effectively improve the implementation of EU law (Coen and Thatcher 2008; Kelemen and Tarrant 2011).

Most explanations of EAN impact are rationalist in nature. Several authors have used PA theory (Egeberg and Trondal 2009; Maggetti 2007, 2014a, 2014b; Yesilkagit 2011), connecting EAN impact to intentional design, bounded rationality and control problems (Bach and Ruffing 2013), empowerment of agencies (Bach and Newman 2010; Bach et al. 2015), strategic use of information (Danielsen and Yesilkagit 2014; Eberlein and Grande 2005) and the hierarchy between ministry and agency (Martens 2008a). At the level of individual agency members, organizational variables like vertical and horizontal specialization have been suggested (Trondal 2011). Finally, peer pressure and reputational dynamics may play a role (Maggetti and Gilardi 2011: 830).

Alternatively, several authors have employed sociological institutionalism to explain EAN impact. Typically, this literature views networks as platforms for continuous interaction between their members, allowing them to engage in knowledge exchange, persuasion and learning - which may lead to the development of joint operating practices (Hobolth and Martinsen 2013: 1411). Accordingly, the capacities of networks can be explained by the way interaction between peers furthers mutual understanding, dialogue and trust (Cengiz 2010; Heidbreder 2015). By interacting on a routine basis, actors are socialized into shared logics and practices. Networks thus may supplement or replace coercive enforcement (Versluis and Tarr 2013). A particularly important mechanism is assumed to be with learning between network members, either horizontally (Hobolth and Martinsen 2013; Zito 2009) or vertically, the network's nodal player becoming a 'teacher of norms' (Versluis and Tarr 2013). As networks for information sharing, exchange of views/ experiences and learning, EANs can improve compliance more effectively than control, deterrence and sanctions (Hobolth and Martinsen 2013). Although the existing literature has advanced insights into the impact of individual networks, we lack research which compares the impact of different 
networks, across time, policy sectors and member states in order to understand and explain whether, when and why EANs improve national implementation and enforcement of EU law and policies.

\section{Normative aspects}

Most literature stresses EANs' positive contribution to European integration their ability to harmonize rules, to create domestic change and to improve compliance (Bach and Newman 2010; Eberlein and Grande 2005; Eberlein and Newman 2008; Hobolth and Martinsen 2013; Maggetti 2014a, 2014b; Maggetti and Gilardi 2014; Martens 2008b; Slaughter 2004). At the same time, EANs raise a set of normative issues, related to the fact that EANs are mostly made up of civil servants and experts from the national and European administrations (Cengiz 2016). Mandating such administrative actors implies processes of depoliticization, devolving power towards the administration and blurring the lines of political responsibility (Bach et al. 2015; Blauberger and Rittberger 2015: 374). The increased autonomy of regulatory networks reduces the influence of formal rule-making institutions (Danielsen and Yesilkagit 2014: 354), thus disempowering (supra)national majoritarian institutions and potentially the Commission as the Union's core executive. Accordingly, decision-making influence further drifts away from national constituencies. As observed by Raustiala (2002: 83) for trans-governmental networks more broadly, these developments are at odds with the thrust of legitimacy theory. While improving effectiveness and rule harmonization, EANs may seriously damage EU legitimacy.

Furthermore, accountability problems loom large (Bignami 2005; Cengiz 2016; Papadopoulos 2007; Smismans 2008).The selective composition and informality of many EAN privileges certain interests at the expense of others (Eberlein and Grande 2005: 106; Papadopoulos 2007; Smismans 2008). Their weak visibility insulates them from public scrutiny. Their decisions are not exposed to parliamentarian involvement, let alone control. Interactions between qualified peers cannot substitute public accountability (Papadopoulos 2007). As argued by Martinsen and Jørgensen (2010), EANs perform poorly from an accountability perspective: there is no forum for holding EANs accountable, they are not obliged to justify their actions and the lack of hierarchy diffuses who is to be held accountable.

Partly remedying these deficiencies, Bignami (2005) has argued that EANs only will emerge if democratically elected governments agree on the underlying policy objectives. Furthermore, governance in networks may foster legitimacy by allowing affected actors to participate in decision-making, which may enhance the acceptance of outcomes and the engagement of citizens more broadly (Börzel and Heard-Lauréote 2009: 144). However, such inclusiveness of EANs is still up for an empirical test. 


\section{Conclusion and research agenda}

An important aspect of the European Administrative Space are European administrative networks, which may fulfil a variety of tasks in the realm of the preparation, making, implementation or enforcement of EU policies. Whereas several other types of networks have received ample attention by the EAS literature, this is not the case for implementation networks. This article set out to describe and integrate the existing insights on these implementing EANs, which are scattered over four different literatures, with the purpose of developing a research agenda on this phenomenon.

The first research theme has been EAN establishment. This is primarily seen as driven by rational considerations, either captured in functionalist or strategic terms - highlighting considerations of effectiveness, power, costs and reputation. In doing so, this literature has broken with the legacy of traditional delegation studies (see Huber and Shipan 2014), which puts substantive policy preferences of principals and agents centre stage for the understanding of processes of delegation. Application of such theories to EAN establishment, which has been seen as a type of delegation, hence seems fruitful. Furthermore, research on the relative importance of the two types of considerations is still in its early stages. Refinement and testing of the integrative theoretical framework by Blauberger and Rittberger (2015) seems warranted. Moreover, the absence of sociological institutionalist theories is striking: processes of socialization, mimicking and learning between sectors, or the activities of norm entrepreneurs, can be expected to predicate EAN establishment. Finally, most empirical work has been Y-oriented, implying a teleological 'reading back' of intentions behind the creation of EANs from the functions that they in fact perform (Thatcher 2011). In order to really determine the conditions of EAN establishment, we should focus on the independent variables and see whether indeed our theories on EAN establishment withstand empirical scrutiny. In doing so, it would be welcome to broaden the empirical scope towards policy domains that have not yet been studied.

EAN functioning, secondly, seems similarly variant. Findings of active and stable co-operation coexist with studies displaying variant co-operation. The level of EAN control by the Commission seems equally disputed. Also, the results so far are based on a selective set of North-western countries, which begs for a more broader scope of research. In addition, more fine-grained comparative analyses are required. First, a theoretical gap concerns explicit modelling of the multiple P-A relations (Dehousse 2008). A particularly interesting question is under what conditions the Commission tries to 'stack the deck' in favour of compliance by enhancing national agencies' autonomy vis-à-vis the government (Busuioc [2016]; Yesilkagit [2011]). Second, much is to be gained from behavioural analyses of network functioning, as well as the application of social network analysis, which is highly suited to analyse 
the extent and antecedents of co-operation and control in networks. This seems especially important because the literature has primarily focused on Commission control, neglecting the question of dominance by powerful national network members (but see Maggetti and Gilardi 2011). Third, the role of the Commission could be studied more extensively; to what extent and under what conditions does it play an effective role of 'teacher of norms' (Versluis and Tarr 2013)? Moreover, how can we explain the differences in effectiveness, co-operation, control and impact on its members? The field could progress greatly through systematic comparative analysis and explanation of variance in network functioning, going beyond North-western member states.

EAN impact, thirdly, has mainly been addressed through rationalist approaches, connecting impact to intentional design, control problems, and the role of agencies among other factors. Other scholars have theorized impact using sociological institutionalism, highlighting the role of mutual adaptation and learning. On a theoretical ground, scholars tend to disagree on EANs' impact on implementation. However, empirical research on whether, when and why EANs do indeed improve national implementation of EU law and policies is scarce. Thus, we call for research on the actual ability of EANs to close the implementation gap. We need more systematic and, indeed, comparative studies to explain if and why EANs matter in the European executive order.

Finally, the normative aspects of implementing EANs have been underemphasized, with the exception of some contributions suggesting problems with legitimacy and accountability. The study of European administrative networks should involve further critical examination of their implications for legitimacy and accountability - both negative and positive. A starting point could be to inquire into relations and interaction between network peers, examine mandating procedures, control and shadows of hierarchy - and embark on an accountability study of EANs beyond the classic input-output dichotomy. Finally, the question whether inclusiveness of EANs may offset these negative side effects, is yet to be determined.

\section{Notes}

1. Whereas the term was originally coined by Olsen (2003), he referred to a different phenomenon: the convergence of national administrations.

2. In selecting the consulted literature, which is fully listed in our Online Appendix, we used a snowballing strategy. Given the limited length of this article, we focused primarily on international journal articles. We mostly excluded the literature on EU agencies, except for studies of agencies with a networked structure (Dehousse 1997, 2008; Groenleer et al. 2010; Levi-Faur 2011; Versluis and Tarr 2013). 
3. Please note that the distinction with European agencies may be thin: many agencies have a networked character, involving national agencies or administrators in their organization (Busuioc 2016; Dehousse 1997; Groenleer et al. 2010; Levi-Faur 2011; Versluis and Tarr 2013). Yet, analytically speaking, networks and agencies are seen as two alternative regulatory design options (Blauberger and Rittberger 2015; Kelemen and Tarrant 2011; Thatcher and Coen 2008).

4. The distinction between functionalist and strategic accounts is often hard to draw: various 'functionalist' accounts focus on the preferences of the main principals involved in EAN creation (Eberlein and Grande 2005; Eberlein and Newman 2008).

\section{Acknowledgements}

The authors would like to thank the participants of the seminar on Compliance and Enforcement in the European Union, Leiden University, Campus The Hague, 21 January 2016, and three anonymous reviewers, for their helpful comments on earlier versions of this article.

\section{Disclosure statement}

No potential conflict of interest was reported by the authors.

\section{Notes on contributors}

Ellen Mastenbroek is professor of European public policy at the Institute for Management Research, Radboud University, The Netherlands.

Dorte Sindbjerg Martinsen is professor at the Department of Political Science, University of Copenhagen, Denmark.

\section{References}

Bach, D. and Newman, A.L. (2010) 'Transgovernmental networks and domestic policy convergence: evidence from insider trading regulation', International Organization 64(03): 505-28.

Bach, T. and Ruffing, E. (2013) 'Networking for autonomy? National agencies in European networks', Public Administration 91(3): 712-26.

Bach, T., Ruffing, E. and Yesilkagit, K. (2015) 'The differential empowering effects of Europeanization on the autonomy of national agencies', Governance 28(3): 285-304.

Bach, T., De Francesco, F., Maggetti, M. and Ruffing, E. (2016) 'Transnational bureaucratic politics: an institutional rivalry perspective on EU network governance', Public Administration 94(1): 9-24.

Bignami, F. (2005) 'Transgovernmental networks vs. democracy: the case of the European information privacy network', Michigan Journal of International Law 26: 807-68.

Blauberger, M. and Rittberger, B. (2015) 'Conceptualizing and theorizing EU regulatory networks', Regulation \& Governance 9: 367-76.

Börzel, T.A. and Heard-Lauréote, K. (2009) 'Networks in EU multi-level governance: concepts and contributions', Journal of Public Policy 29(02): 135-51. 
Busuioc, E. (2016) 'Friend or foe? inter-agency cooperation, organizational reputation, and turf', Public Administration 94(01): 40-56.

Cengiz, F. (2010) 'Multi-level governance in competition policy: the European competition network', European Law Review 35(5): 660-77.

Cengiz, F. (2016) 'Legitimacy and multi-level governance in European Union competition law: a deliberative discursive approach', JCMS: Journal of Common Market Studies 54(4): 826-45.

Coen, D. and Thatcher, M. (2005) 'The new governance of markets and non-majoritarian regulators', Governance 18(3): 329-46.

Coen, D. and Thatcher, M. (2008) 'Network governance and multi-level delegation: European networks of regulatory agencies', Journal of Public Policy 28(01): 49-71.

Danielsen, O.A. and Yesilkagit, K. (2014) 'The effects of European regulatory networks on the bureaucratic autonomy of national regulatory authorities', Public Organization Review 14(3): 353-71.

Dehousse, R. (1997) 'Regulation by networks in the European community: the role of European agencies', Journal of European Public Policy 4(2): 246-61.

Dehousse, R. (2008) 'Delegation of powers in the European Union: the need for a multiprincipals model', West European Politics 31(4): 789-805.

Eberlein, B. and Grande, E. (2005) 'Beyond delegation: transnational regulatory regimes and the EU regulatory state', Journal of European Public Policy 12(1): 89-112.

Eberlein, B. and Newman, A.L. (2008) 'Escaping the international governance dilemma? Incorporated transgovernmental networks in the European Union', Governance 21 (1): 25-52.

Egeberg, M. (2006) 'Europe's executive branch of government in the melting pot: an overview', in M. Egeberg (ed.), Multilevel Union Administration. The Transformation of Executive Politics in Europe, Basingstoke: Palgrave Macmillan, pp. 1-16.

Egeberg, M. and Trondal, J. (2009) 'National agencies in the European administrative space: government driven, commission driven or networked?', Public Administration 87(4): 779-90.

Groenleer, M., Kaeding, M. and Versluis, E. (2010) 'Regulatory governance through agencies of the European Union? The role of the European agencies for maritime and aviation safety in the implementation of European transport legislation', Journal of European Public Policy 17(8): 1212-30.

Heidbreder, E.G. (2015) 'Multilevel policy enforcement: innovations in how to administer liberalized global markets', Public Administration 93(4): 940-955.

Hobolth, M. and Martinsen, D.S. (2013) 'Transgovernmental networks in the European Union: improving compliance effectively?', Journal of European Public Policy 20(10): 1406-24.

Hofmann, H.C.H. (2008) 'Mapping the European administrative space', West European Politics 31(4): 662-76.

Hollis, S. (2010) 'The necessity of protection: transgovernmental networks and EU security governance', Cooperation and conflict 45(3): 312-30.

Huber, J.D. and Shipan, C.R. (2014) 'Politics, delegation, and bureaucracy', in R.E. Goodin (ed.), The Oxford Handbook of Political Science, Oxford: Oxford University Press, pp. 1-13. doi:10.1093/oxfordhb/9780199604456.013.0041.

Kassim, H. and Wright, K. (2009) 'Bringing regulatory processes back in: the reform of EU antitrust and merger control', West European Politics 32(4): 738-55.

Kelemen, R.D. and Tarrant, A.D. (2011) 'The political foundations of the Eurocracy', West European Politics 34(5): 922-47. 
Levi-Faur, D. (2011) 'Regulatory networks and regulatory agencification: towards a single European regulatory space', Journal of European Public Policy 18(6): 810-29.

Maggetti, M. (2007) 'De facto independence after delegation: a fuzzy-set analysis', Regulation \& Governance 1(4): 271-94.

Maggetti, M. (2014a) 'The politics of network governance in Europe: the case of energy regulation', West European Politics 37(3): 497-514.

Maggetti, M. (2014b) 'The rewards of cooperation: the effects of membership in European regulatory networks', European Journal of Political Research 53(3): 480-99.

Maggetti, M. and Gilardi, F. (2011) 'The policy-making structure of European regulatory networks and the domestic adoption of standards', Journal of European Public Policy 18(6): 830-47.

Maggetti, M. and Gilardi, F. (2014) 'Network governance and the domestic adoption of soft rules', Journal of European Public Policy 21(9): 1293-310.

Majone, G. (2000) 'The credibility crisis of community regulation', JCMS: Journal of Common Market Studies 38(2): 273-302.

Martens, M. (2008a) 'Runaway bureaucracy? Exploring the role of nordic regulatory agencies in the European Union', Scandinavian Political Studies 31(1): 27-43.

Martens, M. (2008b) 'Administrative integration through the back door? The role and influence of the European Commission in transgovernmental networks within the environmental policy field', Journal of European Integration 30(5): 635-51.

Martinsen, D.S. and Jørgensen, T.B. (2010) 'Accountability as a differentiated value in supranational governance', The American Review of Public Administration 40(6): 742-60.

Mathieu, E. (2015) 'When Europeanization feeds back into EU governance: EU legislation, national regulatory agencies, and EU regulatory networks', Public Administration 94(01): 25-39.

McGowan, L. (2005) 'Europeanization unleashed and rebounding: assessing the modernization of EU cartel policy', Journal of European Public Policy 12(6): 986-1004.

Metcalfe, L. (2000) 'Reforming the Commission: will organizational efficiency produce effective governance?', JCMS: Journal of Common Market Studies 38(5): 817-41.

Newman, A.L. (2008) 'Building transnational civil liberties: transgovernmental entrepreneurs and the European data privacy directive', International Organization 62(01): 103-30.

Olsen, J. (2003) 'Towards a European administrative space?', Journal of European Public Policy 10(4): 506-31.

Papadopoulos, Y. (2007) 'Problems of democratic accountability in network and multilevel governance', European law journal 13(4): 469-86.

Raustiala, K. (2002) 'The architecture of international cooperation: transgovernmental networks and the future of international law', Virginia Journal of International Law 43(01): 1-92.

Slaughter, A.-M. (2004) A new world order, Princeton: Princeton University Press.

Slaughter, A.-M. and Hale, T. (2010) 'Transgovernmental networks', in M. Bevir (ed.), The Handbook of Governance, Thousand Oaks, CA: SAGE Publishing, pp. 342-51.

Smismans, S. (2008) 'New modes of governance and the participatory myth', West European Politics 31(5): 874-95.

Thatcher, M. (2011) 'The creation of European regulatory agencies and its limits: a comparative analysis of European delegation', Journal of European Public Policy 18(6): 790-809.

Thatcher, M. and Coen, D. (2008) 'Reshaping European regulatory space: an evolutionary analysis', West European Politics 31(4): 806-836. 
Thurner, P.W. and Binder, M. (2009) 'European Union transgovernmental networks: the emergence of a new political space beyond the nation-state?', European Journal of Political Research 48(1): 80-106.

Trondal, J. (2010) An emergent European executive order, Oxford: OUP.

Trondal, J. (2011) 'Domestic agencies in an emergent European executive order', Journal of European Integration 33(1): 55-74.

Trondal, J. and Peters, B.G. (2013) 'The rise of European administrative space: lessons learned', Journal of European Public Policy 20(2): 295-307.

Van Boetzelaer, K. and Princen, S. (2012) 'The quest for co-ordination in European regulatory networks"', JCMS: Journal of Common Market Studies 50(5): 819-36.

Versluis, E. and Tarr, E. (2013) 'Improving compliance with European Union law via agencies: the case of the European railway agency', JCMS: Journal of Common Market Studies 51(2): 316-33.

Vifell, Å.C. and Sjögren, E. (2014) 'The legal mind of the internal market: a governmentality perspective on the judicialization of monitoring practices', JCMS: Journal of Common Market Studies 52(3): 461-78.

Wilks, S. (2005) 'Agency escape: decentralization or dominance of the European Commission in the modernization of competition policy?', Governance 18(3): 431-52.

Yesilkagit, K. (2011) 'Institutional compliance, European networks of regulation and the bureaucratic autonomy of national regulatory authorities', Journal of European Public Policy 18(7): 962-79.

Zito, A.R. (2009) 'European agencies as agents of governance and EU learning', Journal of European Public Policy 16(8): 1224-43. 